\title{
Edukacja dla bezpieczeństwa widowisk sportowych
}

\author{
Abstract \\ Education for security of athletics spectacle
}

\begin{abstract}
Athletics spectacle as a social event of light character, in which both sides of interaction take part - athletes and spectators - could have double nature: positive and negative. What sort of emotions will be evoked at the pitch, depend on correct arrangement of the event, competitors and mostly depend on followers, their culture and behavior habits. Characteristic feature for athletics audience is its division into groups. During the spectacle time, groups occupy the sectors that are appointed by organizers and that area becomes their patch where is accepted by fans behavior style, unity of feelings and reactions. For years during athletics spectacle, there have appeared many symptoms of aggression, racist behaviors, vulgarisms and lack of tolerance for years. In this article it was presented completed education agendas aimed at young followers and also professing norms and values by the groups of pseudo-rooters, during eight years period.
\end{abstract}

\section{Wprowadzenie}

Termin „widowisko sportowe” jest ściśle związany z widowiskową stroną zdarzenia sportowego, które może mieć postać meczu, wyścigów, zawodów, rajdu oraz przebiega w określonym miejscu i czasie. Według Kosiewicza widowisko sportowe ujmowane jest jako audiowizualne - wizualne zdarzenie sportowe o charakterze ludycznym, rozrywkowo-rekreacyjnym, którego celem jest głównie prezentacja rywalizacji sportowej, umiejętności i popisów zręcznościowych zawodników - z uwzględnieniem, że rywalizacja przebiega zgodnie z uznanymi regułami i przepisami, a związana jest z uczestnictwem zawodników, sędziów, organizatorów oraz widzów nawzajem oddziałujących na siebie w trakcie spektaklu 
(Kosiewicz 2004, s. 191). Jak można zauważyć, widowisko sportowe nie polega na samym oglądaniu czynności zawodników, lecz jest skomplikowanym splotem reguł i więzi społecznych między zawodnikami, trenerem, organizatorami, sędziami i widzami. Jego przebieg zależy od motywacji uczestnictwa, oczekiwań rezultatów sportowych, oczekiwań wobec widowiska, liczby uczestników, ich kultury i nawyków zachowania.

W dawnych czasach widownia była jedynie nieznaczącym dodatkiem do widowiska. Niewielka grupa widzów koncentrowała się na tym, co mogła zaobserwować, czyli na grze zawodników, która to gra była celem samym w sobie. W czynności sportowe zaangażowani byli jedynie sami uczestnicy. Z czasem jednak atrakcyjność zmagań przyciągała coraz więcej ludzi tym zainteresowanych, którzy z uwagą śledzili dane zawody. Obecnie zaś widowiska sportowe są tworzone przez przemysł sportowo-rozrywkowy, zawody organizowane są dla widzów i mają zaspokajać oczekiwania publiczności.

Dzisiejsza stutysięczna publiczność stadionowa jest nieporównywalna $z$ tą w latach 20. XX wieku, która oklaskiwała swoją drużynę. Zmiany, jakie zaszły na trybunach, można przedstawić jako przemianę hobby w profesjonalną działalność, precyzyjna organizacja zastąpiła spontaniczność. W tym zakresie dostrzega się potrzebę profesjonalizacji procesu organizacji czy też reżyserii zawodów sportowych, ukierunkowanych nie tylko na wzrost ich atrakcyjności, lecz również na bezpieczeństwo uczestników.

Cechą charakterystyczną widowni sportowej jest podział na grupy wynikający, co istotne, nie tyle z ich zainteresowań, ale ze względu na podzielane przez nie uczucia, przeświadczenia, oceny. Tworzą je kibice rywalizujących ze sobą drużyn. Na czas widowiska grupy te zajmują wyznaczone przez organizatorów sektory, które stają się ich terytorium. Obowiązuje na nim akceptowany przez fanów styl zachowania, jedność uczuć i reakcji. Jeśli zatem na takim terytorium umyślnie lub przypadkowo znajdują się kibice - przeciwnicy, dochodzi do scysji, kłótni, a nawet rękoczynów. Podział widzów, który zdaniem Piotrowskiego jest triadyczny, przebiega następująco: pierwszą grupę stanowią konsumenci lub „prawdziwi kibice”. Są to przeważnie osoby w dojrzałym wieku, o stabilnej sytuacji finansowej i dobrej pozycji społecznej. Ta część publiczności przychodzi na stadion przede wszystkim po to, aby uczestniczyć w dobrym widowisku sportowym. Wynik meczu jest dla niej sprawą drugorzędną, a zachowania są zgodne z regułą fair play. Szuka w widowisku doznań estetycznych, potrafi docenić i nagrodzić oklaskami wysiłek drużyny rywala, a jej poczynania są wolne od agresji (Piotrowski 2000, s. 10).

Drugą grupę tworzą kibice lub inaczej fani. Tym, co odróżnia ich od widzów, jest stopień emocjonalnego zaangażowania po stronie jednej z walczących drużyn. Są to w większości młodzi ludzie, identyfikujący się silnie ze swoim zespołem. Przychodzą na stadion, aby zobaczyć, jak drużyna, której kibicują, zwycięża rywala. Sam przebieg zawodów oraz ich poziom mają dla nich znaczenie marginalne. Zwycięstwo ulubionego zespołu traktowane jest w kategoriach osobistego sukcesu, porażka staje się osobistą klęską. Zawodnicy drużyny przeciwnej, wspierający ich kibice są postrzegani jako przeszkoda, którą należy usunąć po to, aby „nasi” zwyciężyli. Porażka jest zdarzeniem silnie frustrującym i często 
prowadzi do aktów agresywnego odwetu. Celem jest poniżenie rywala, a plamę na honorze, jaką jest przegrana na boisku, można zmazać na trybunach lub w pomeczowych starciach (Piotrowski 2000, s. 10).

Trzecią część publiczności stanowią chuligani stadionowi. Głównym powodem, dla którego przychodzą na mecze, bynajmniej nie jest pragnienie oglądania sportowych zawodów. Wynik nie ma dla nich większego znaczenia. Stadion jest miejscem, gdzie mogą zaspokoić potrzebę silnych wrażeń, znaleźć się w sytuacji pełnej napięcia i ryzyka. Grupki tego rodzaju widzów pojawiają się przede wszystkim tam, gdzie istnieje prawdopodobieństwo starć z siłami porządkowymi lub kibicami drużyny rywala (Piotrowski 2000, s. 11).

Własnej klasyfikacji osób pojawiających się na sportowych imprezach masowych dokonała Policja. W Załączniku do decyzji nr 57 Komendanta Głównego Policji z dnia 1 lutego 2005 r. znajduje się klasyfikacja uczestników masowych imprez sportowych, która dzieli bywalców piłkarskich stadionów na trzy kategorie. Kluczem do podziału kibiców były ich stosunek do agresji na stadionach i ocena realności zagrożenia, że dana osoba może stać się prowodyrem lub czynnym uczestnikiem agresywnych zachowań. Podział prezentuje się następująco (Komendant Główny Policji 2005, s. 190-194):

1) kategoria A - uczestnicy imprez, którzy na podstawie dotychczasowych doświadczeń nie wywołują i nie uczestniczą w awanturach i zakłóceniach porządku publicznego niezależnie od zaistniałych okoliczności;

2) kategoria B - uczestnicy imprez, którzy na podstawie dotychczasowych doświadczeń mogą w określonych sytuacjach, pod wpływem bodźców zewnętrznych uczestniczyć w naruszeniach porządku publicznego i prowokować negatywne zachowania zgromadzonych;

3) kategoria C - uczestnicy imprez, którzy na podstawie dotychczasowych doświadczeń za główny cel swojej obecności przyjmują chęć wyżycia się, zamanifestowania swojego stanowiska poprzez wywołanie awantur lub konfrontację z innymi uczestnikami imprezy bądź też siłami porządkowymi.

Zaproponowany przez Policję podział struktury kibiców wydaje się adekwatny do istniejącego stanu rzeczy i nie powoduje ich gloryfikacji poprzez stosowane nazewnictwo, co można spotkać nagminnie w literaturze przedmiotu. Takie rozróżnienie staje się łatwiejsze w prowadzonej pracy spottersów i innych służb odpowiedzialnych za utrzymanie bezpieczeństwa w trakcie widowisk sportowych.

Liczne frustracje przeżywane przez widzów w trakcie widowiska nie kończą się wraz z zamknięciem imprezy. Często już w drodze do domu dochodzi do awantur, bójek zwycięzców i pokonanych. Inni rozładowują frustrację w pociągach, autobusach, atakując wszystko i wszystkich. Nie jest to zbyt optymistyczna wizja społeczeństwa podporządkowanego hordom pseudokibiców pustoszących miasta, stanowiących zagrożenie nie tylko dla siebie nawzajem, ale i pozostałych obywateli niezwiązanych z wydarzeniami sportowymi.

Znaczenie problematyki określanej mianem bezpieczeństwa sportowych imprez masowych jest szczególnie widoczne w sytuacjach naruszeń prawa w miejscu i czasie odbywania się tych imprez - zawodów sportowych - przez część osób 
w nich uczestniczących. Jest to jednocześnie jedna z patologii odciskających piętno na współczesnym sporcie (Krawczyk 2000, s. 13), której nie wszyscy organizatorzy potrafią się skutecznie przeciwstawiać. Taki stan faktyczny funkcjonuje od wielu lat, a podejmowane próby przeciwdziałania tym negatywnym tendencjom przynoszą dość ograniczone rezultaty. Postępujące przemiany cywilizacyjne oraz dokonujące się w nowoczesnych demokracjach zmiany: gospodarcze, społeczne, kulturowe, polityczne - oprócz swoich widocznych pozytywnych następstw ukierunkowanych m.in. na stworzenie społeczeństwa obywatelskiego czy też zaspokojenie potrzeby egzystencjalnej, jaką jest potrzeba „szczęścia” - przyniosły wraz ze sobą również szereg niepożądanych zjawisk obejmujących społeczne straty, strach oraz cierpienie wielu jednostek (Krzyżak-Szymańska, Szymański 2005, s. 15). Bez wątpienia do tych zjawisk, sprzecznych z uniwersalnym porządkiem aksjonormatywnym, zaliczyć należy zachowania agresywne grup pseudokibiców. Jest to problem o złożonym charakterze, jako że demokratyzujące się społeczeństwo z jednej strony oczekuje stosunkowo wysokiego poziomu wolności dla jednostki, z drugiej zaś spotyka się z ograniczeniami tej wolności, choćby poprzez przeciwdziałanie ekstremalnym formom zachowań widzów (Krawczyk 2000, s. 9). W tym obszarze można więc wyodrębnić aspekty związane $z$ widownią sportową, a wśród nich jej szczegółowe zachowania w wymiarze tak indywidualnym, jak i zbiorowym. Należy przy tym uwzględnić tę część publiczności, która respektuje normy prawne i uczestniczy w widowisku dla sportu, jak też tę, której wyłącznym celem jest to, aby w sprzyjającym momencie ,zaistnieć” w nim poprzez działania naruszające obowiązujący porządek prawny, akty wandalizmu czy przejawy wzajemnej agresji.

Chuligaństwo stadionowe nie jest nowym problemem, który pojawił się na przestrzeni ostatnich lat. Już w odległych czasach starożytnych kibice nie czuli się bezpiecznie na stadionach. Podczas imprez sportowych dochodziło do bójek, rzezi i katastrof budowlanych, w których ginęły tysiące ludzi. Burdom chuligańskim w starożytności sprzyjały olbrzymie obiekty sportowo-rozrywkowe, mieszczące niekiedy ponad 100 tysięcy osób. Ponadto tej olbrzymiej liczby ludzi nikt nie był w stanie kontrolować, nie istniały też zorganizowane siły porządkowe i policyjne jak w dzisiejszych czasach.

Dzisiejsze futbolowe chuligaństwo narodziło się w Wielkiej Brytanii na przełomie lat 60. i 70. ubiegłego wieku. Początkowo piętnowane jako niebezpieczne zjawisko, nazywane „angielską chorobą”, w szybkim tempie zyskało wymiar międzynarodowy i rozprzestrzeniło się wśród młodzieży innych krajów, w których piłka nożna cieszy się największą popularnością. Coraz częstsze wybryki chuligańskie destabilizowały organizację wydarzeń sportowych i przyczyniały się do zwiększenia zagrożenia przestępczością. Dodatkowe zaniepokojenie budziły rasistowskie i nazistowskie symbole i hasła prezentowane przez niektóre grupy kibiców.

Problem bagatelizowano aż do czasu, gdy zachowania kibiców przybrały charakter zorganizowanej działalności nastawionej na dokonywanie regularnych zamachów na porządek i bezpieczeństwo publiczne (Radawniak 2011, s. 37-38). Tragedia na Heysel (jej bilans wyniósł 39 zabitych i ponad 600 rannych) była momentem przełomowym w historii walki z chuligaństwem stadionowymi. Decydenci 
zrozumieli, że bez podjęcia rygorystycznych środków nie uda się wyprzeć chuligaństwa z piłkarskich aren. Niezbędne okazało się wsparcie władz federacji piłkarskiej oraz klubowych, którym - przynajmniej częściowo - podporządkowali się również przedstawiciele kibiców. Chuligani, utożsamiający się z konkretną drużyną, zrozumieli, że za ich wybryki płacić będą nie tylko oni (kary finansowe, zakazy stadionowe, kary więzienia), ale także klub (dyskwalifikacje i walkowery, odjęcia punktów, kary finansowe, zamknięte trybuny i stadiony). Taktyka ponoszenia konsekwencji za chuligańskie wybryki zarówno przez środowisko kibiców, jak i kluby sportowe wydaje się sprawdzać i w pewnym stopniu ograniczać niepożądane zachowania, które negatywnie wpływają na bezpieczeństwo sportu. Bez wątpienia rozwiązania problemu chuligaństwa stadionowego nie można upatrywać tylko i wyłącznie w ostrzejszym prawie, zwiększonej liczbie zakazów czy sprawniej działającej Policji lub nałożeniu większej liczby obowiązków na organizatorów imprez masowych. Pożądaną drogą jest prowadzenie szeroko pojętej profilaktyki oraz tworzenie warunków przez szkoły i kluby sportowe do uprawiania sportu i przekazywania jego naczelnych wartości.

\section{Bezpieczeństwo widowisk sportowych jako element edukacji dla bezpieczeństwa}

Bezpieczeństwo można określić jako ,,stan niezagrożenia, spokoju” (Skorupka, Auderska, Łempicka 1990, s. 40), który sprzyja możliwości istnienia i rozwoju ludzi. Stanowi ono jedną z podstawowych potrzeb człowieka, w szerszym zaś wymiarze grup społecznych, organizacji czy państw. Determinuje je zwłaszcza poczucie braku ryzyka utraty dobra szczególnie cennego, jakim może być mienie, zdrowie lub życie. Symptomatyczny jest także brak zagrożenia, postrzegany jako immanentna część procesu zapewniania ludziom bezpieczeństwa. Bezpieczeństwo może być różnie klasyfikowane, jednak najwłaściwsze wydaje się dokonywanie tego podziału ze względu na dziedzinę, do jakiej się ono odnosi. Definicją stojącą najbliżej omawianej problematyki jest bezpieczeństwo publiczne, określane jako ,,ogół warunków i instytucji chroniących życie, zdrowie i mienie obywateli oraz majątek ogólnonarodowy (1/4) przed zjawiskami groźnymi dla ładu prawnego" (Rawicz, Bylińska-Czemeszczyk, Mazierska, Ostrowska, Jewdikimow, Godlewski 2005, s. 337). Jego istotną część stanowi również sfera bezpieczeństwa widowiska sportowego, wpisująca się we wszystkie wyżej wskazane obszary. W Polsce obowiązujące w tym zakresie szczegółowe definicje zawarte zostały w podstawowym akcie prawnym, jakim jest Ustawa z dnia 20 marca 2009 r. o bezpieczeństwie imprez masowych (Dz.U. z 2009 r. Nr 62, poz. 504), która wraz z aktami wykonawczymi stanowi swoiste kompendium postępowania dla organizatorów, których celem jest zapewnienie bezpieczeństwa uczestnikom imprez masowych.

Kolejną istotną grupę regulacji tworzą przepisy prawa związkowego, mające najczęściej postać uchwał bądź regulaminów. Odnoszą się one do wszystkich kwestii związanych z organizacją meczu piłkarskiego, a w szczególności: regulacji 
w zakresie systemu licencyjnego, spraw dyscyplinarnych oraz regulaminów rozgrywek, ustalanych osobno dla kolejnych poziomów rozgrywek szczebla centralnego, a także bezpieczeństwa na obiektach piłkarskich. Zakres przedmiotowy tych przepisów swoją szczegółowością znacznie przewyższa zapisy ustawy i są one skoncentrowane wyłącznie na organizacji bezpieczeństwa meczu piłkarskiego. Kluczowym dokumentem dla wszystkich podmiotów uczestniczących w rozgrywkach piłkarskich w Polsce jest regulamin bezpieczeństwa rozgrywek prowadzonych przez PZPN i Ekstraklasę S.A. (Uchwała nr X/110 z dnia 10.07.2010 Zarządu PZPN w sprawie przyjęcia Regulaminu w zakresie bezpieczeństwa podczas rozgrywek organizowanych przez PZPN i Ekstraklasa S.A.).

Charakterystyczne dla każdej działalności człowieka jest świadome dążenie do określonych celów, które nakierowane jest na zaspokajanie potrzeb. Potrzeby te charakteryzuje układ hierarchiczny, obejmujący sekwencję od tych najbardziej podstawowych do tych na wyższym poziomie. Zwykle zachowanie ludzkie jest motywowane w ten sposób, że dana jednostka w pierwszej kolejności odczuwa przymus realizacji potrzeby niższego rzędu, a dopiero w następnej kolejności odczuwa potrzebę rzędu wyższego i chęć jej spełnienia z chwilą, gdy poprzednie potrzeby zostały zaspokojone w sposób względnie zadowalający. Obrazowo ten schemat realizacji potrzeb przedstawił A. Maslow. W układzie tym, mającym konstrukcję piramidy, bezpieczeństwo znajduje się na drugim miejscu tuż za potrzebami wiscerogennymi. Potrzeby bezpieczeństwa pobudzają do działań zapewniających organizmowi nienaruszalność. Zalicza się do nich takie elementy, jak spokój, opieka i oparcie, wolność od strachu, protekcja i wygoda. Ujawniają się wtedy, gdy doznajemy bólu, jesteśmy chorzy, przeżywamy wojnę, klęski żywiołowe, kiedy tracimy pewność i stabilność swego bytu. Zaspokojenie tych czynników stwarza możliwość wspinania się po kolejnych szczeblach piramidy i realizacji obranych przez nas dalszych celów. Widzimy więc, że zaburzona realizacja tej fundamentalnej potrzeby powoduje paraliż pewnego ciągu naszych działań. Tym samym możemy stwierdzić, że potrzeba bezpieczeństwa we współczesnym świecie jest węzłowa dla naszego życia, funkcjonowania i dalszego rozwoju. Jej zaspokojenie w dużej mierze zależne jest od tego, w jaki sposób stajemy się jej społecznym konsumentem i jak jesteśmy do tego przygotowani, to jest jak przebiegała (przebiega) nasza edukacja dla bezpieczeństwa.

Aby mówić o edukacji dla bezpieczeństwa, w pierwszej kolejności należy zdefiniować wskazane pojęcie. Według MEN edukacja dla bezpieczeństwa to: dział edukacji narodowej, którego głównym celem jest przygotowanie do racjonalnych zachowań w obliczu zagrożeń cywilizacyjnych i militarnych. Zatem celem edukacji dla bezpieczeństwa, a w szerszym ujęciu - bezpieczeństwa w trakcie imprez sportowych, jest upowszechnianie świadomości i wiedzy o źródłach, charakterze i skutkach zagrożeń oraz opanowania umiejętności rozpoznawania, zapobiegania i przeciwstawienia się tego rodzaju niebezpieczeństwom. Pytaniem, które w tym kontekście się rodzi, jest kwestia tego, w jaki sposób, jako odbiorcy widowisk sportowych, jesteśmy edukowani, kto tę edukację realizuje i w jakich obszarach jest ona lokowana.

Aktem prawnym regulującym kwestie edukacji jest Ustawa o systemie oświaty (Dz.U. z 2004 r. Nr 256, poz. 2572 z póź. zmianami). Ustawa ta w art. 1 ust. 16 jako 
jedno z podstawowych zadań nauczania określa upowszechnianie wśród dzieci i młodzieży wiedzy o bezpieczeństwie oraz kształtowanie właściwych postaw wobec zagrożeń i sytuacji nadzwyczajnych. Swoistym rozwinięciem tego i innych zadań systemu oświaty jest Rozporządzenie Ministra Edukacji Narodowej z dnia 27 sierpnia 2012 roku w sprawie podstawy programowej wychowania przedszkolnego oraz kształcenia ogólnego w poszczególnych typach szkół. Określa ono, w programie jakich przedmiotów i w obrębie których ścieżek edukacyjnych uczniowie poznają treści i uzyskują umiejętności w zakresie tzw. edukacji dla bezpieczeństwa. Edukacja ta nastawiona jest na treści związane z zagrożeniami w najbliższym środowisku. Poruszane są problemy zagrożeń środowiska naturalnego, zagrożeń pożarowych i innych charakterystycznych dla rejonu, w którym przebywa uczeń. Powyższe treści nie stanowią odrębnego przedmiotu nauczania, lecz są wkomponowane w różne tematy kilku przedmiotów.

Co warte podkreślenia, problematyka edukacji dla bezpieczeństwa leży nie tylko w zakresie kompetencji ministra właściwego do spraw edukacji ( $z$ uwagi na przypisanie mu zadań z zakresu oświaty), ale również obejmuje Ministra Spraw Wewnętrznych (ze względu na zadania w zakresie szeroko rozumianego bezpieczeństwa i porządku publicznego). Ten drugi w proces edukacji dla bezpieczeństwa, w tym dla bezpieczeństwa widowni sportowych, mocno angażuje Policję - ustawowo odpowiedzialną za kwestię zapewnienia porządku i bezpieczeństwa powszechnego. W ustawie, oprócz ustanowienia ogólnej powinności Policji, sformułowano wobec niej także szereg oczekiwań (zadań), co należy uznać za określenie jej roli jako organizacji formalnej, działającej na rzecz istniejącego systemu społeczno-politycznego. W zasadniczym wymiarze rolę tę zawarto w takich zadaniach, jak: ochrona życia i zdrowia ludzi oraz mienia przed bezprawnymi zamachami, naruszającymi te dobra, zapewnienie spokoju w miejscach publicznych, czy choćby uruchamianie i organizowanie działań z zakresu prewencji kryminalnej. Ustawa, co do zasady, nie precyzuje sposobu realizacji przedmiotowej problematyki, pozostawiając w tym zakresie swobodę decyzji samej organizacji.

Inicjatywy dotyczące zapewnienia bezpieczeństwa społeczeństwa realizowane są również na wszystkich poziomach administracji publicznej (rządowej i samorządowej). Główną rolę koordynatora odgrywają urzędy wojewódzkie, realizując m.in. założenia programu „Razem Bezpieczniej”. Program ten ma za zadanie ograniczyć skalę zjawisk i zachowań, które budzą powszechny sprzeciw i poczucie zagrożenia. Do najważniejszych obszarów, w których podjęto działania w ramach programu, należy zaliczyć m.in. bezpieczeństwo w miejscach publicznych i w miejscu zamieszkania ${ }^{1}$, w tym na stadionach w trakcie odbywania się imprez masowych sportowych. Zadaniu temu mają służyć programy prewencyjne oraz profilaktyczne kierowane do odbiorców imprez masowych. Podstawowym projektem w tym obszarze jest ogólnopolski program edukacyjno-alternatywny kształtujący pozytywne zachowania dzieci i młodzieży jako uczestników imprez sportowych pt. „Jestem Kibicem przez duże K”2.

1 Ogólne założenia programu „Razem bezpieczniej”, który został przyjęty przez Radę Ministrów 18.11.2006 r.

2 Autorem projektu jest Biuro Prewencji Komendy Głównej Policji, które do realizacji niniejszego programu zaprosiło: Biuro Pełnomocnika Rządu ds. Równego Traktowania, Ministerstwo Spraw 
W programie „Jestem kibicem przez duże K” zaplanowano działania oparte na dwóch strategiach profilaktycznych: strategii edukacyjnej i strategii alternatywnej (patrz rysunek 1).

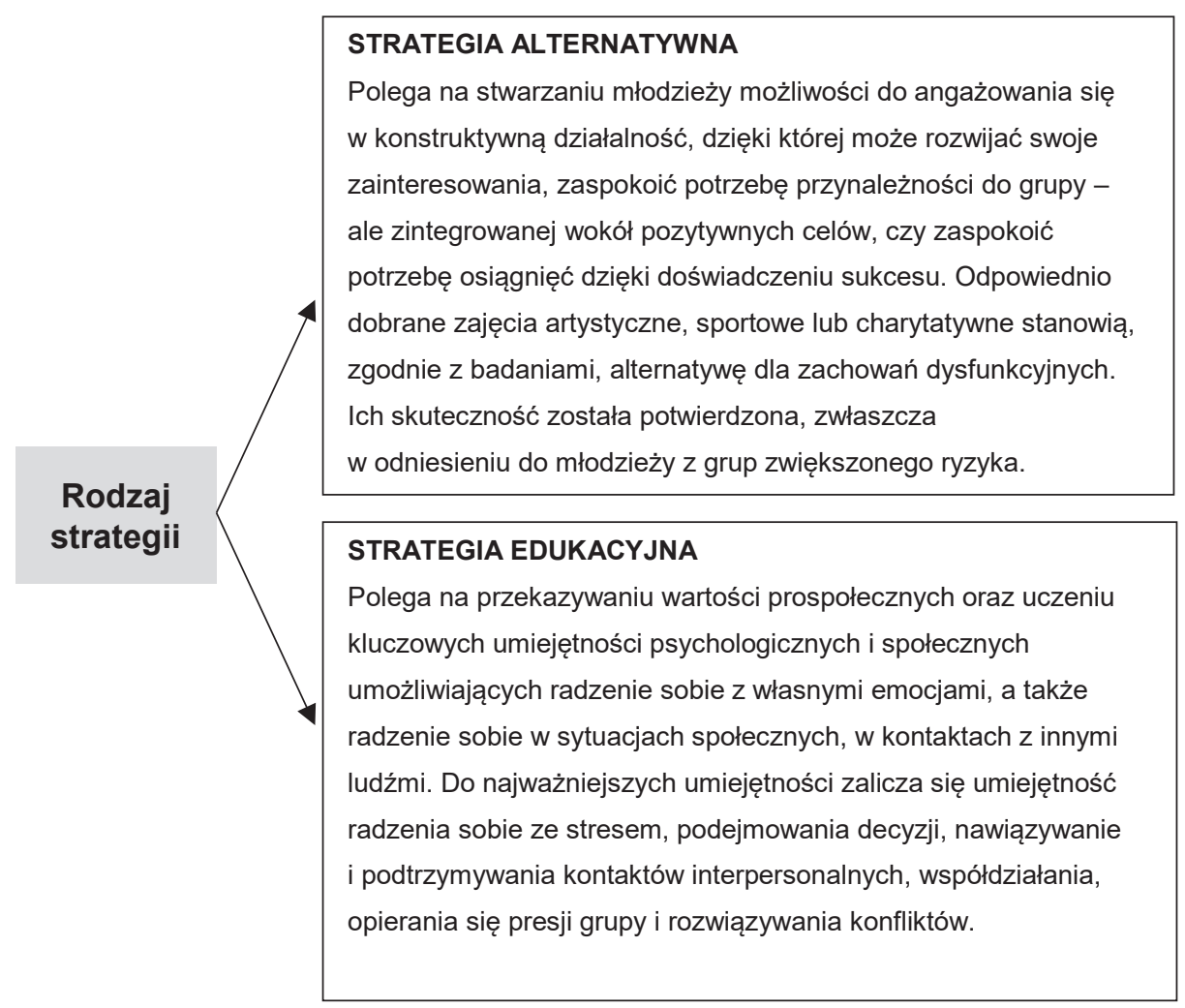

Rysunek 1. Rodzaje strategii

Źródło: opracowanie własne na podstawie programu "Jestem kibicem przez duże K”.

Innym wartościowym programem o charakterze regionalnym jest program pt. „Jestem Fair” (Kowalska, Kaźmierczak 2010), którego celem jest propagowanie idei fair play w sporcie, na stadionie i w życiu, jako edukacyjnego elementu zwalczania rasizmu, ksenofobii i antysemityzmu, oraz upowszechnianie postawy większego zrozumienia dla innych kultur i wyznań i większej tolerancji wśród dzieci kończących szkołę podstawową mieszkających w Łodzi - w okolicy stadionów ŁKS i Widzew oraz w Śródmieściu³.

Wewnętrznych i Administracji, Ministerstwo Edukacji Narodowej, Ministerstwo Sprawiedliwości, a także Polski Komitet Olimpijski, Państwową Agencję Rozwiązywania Problemów Alkoholowych, Fundację na Rzecz Wspierania Edukacji Szkolnej oraz Główny Sztab Policji Komendy Głównej Policji.

3 Realizatorami programu w latach 2009-2010 byli Pracownia Wychowania Fizycznego i Zdrowotnego Wydziału Nauk o Wychowaniu UŁ, studenci kierunku pedagogika ze specjalnością 
Kolejnym regionalnym programem dotyczącym bezpieczeństwa na widowniach sportowych, który jest realizowany na terenie województwa śląskiego, jest program „Bezpieczny i przyjazny stadion”. Głównym celem tego przedsięwzięcia jest wykształcenie właściwych, pożądanych postaw u młodego człowieka oraz nauczenie go zachowań odpowiednich i niezbędnych dla właściwego dopingowania sportowego (kibicowania). Celem pośrednim, a zarazem warunkiem dobrego funkcjonowania programu, jest integracja instytucji, podmiotów i środowisk odpowiedzialnych za rozwój sportu i kultury fizycznej. W programie biorą udział dzieci i młodzież ze szkół podstawowych (klasy IV-VI), gimnazjalnych oraz ponadgimnazjalnych (ogólnokształcących, zawodowych). Działania programu dostosowane są do poziomu edukacyjnego uczestników. Koordynatorem jest Stowarzyszenie Kultury Fizycznej Uczniowski Klub Sportowy 06 Katowice-Południe (nazwa skrócona UKS Południe). Autorzy programu wychodzą z założenia, że im bardziej „wyjdzie się w stronę” dzieci i młodzieży, naprzeciw ich oczekiwaniom, im bardziej zbliży się do nich, pozna ich świat i poświęci się im czas w ich miejscach pracy (szkołach), tym efektywność wszelkich działań jest większa. Dlatego też proponują, aby wejść do szkół i tam spotkać się z dziećmi i młodzieżą - obecnymi i przyszłymi kibicami (Wróblewski, Sośniak 2008, s. 3).

\section{Normy i wartości deklarowane przez pseudokibiców}

Do bezpiecznego funkcjonowania w życiu młode pokolenie Polaków powinna wdrażać nie tylko szkoła, lecz przede wszystkim rodzina. To ona jest bowiem pierwszym środowiskiem wychowawczym dziecka, w którym przekazywane są mu podstawowe przyzwyczajenia, normy i umiejętności, bez których udział w społeczeństwie byłby niemożliwy (Wiatr 1983, s. 59). Wybór zachowania jest "determinowany uznawaną wartością pełniej niż określoną postawą" (Matusewicz 1975 , s. 224). Dlatego przewidywalność ludzkich zachowań powinna być oparta bardziej na wiedzy o wartościach niż na wiedzy o postawach. Ponadto zachowanie zmierzające do realizacji określonego celu nasycone jest wartością i poprzez nią uzyskuje walor dobra. Wskazanie celu zachowania odkrywa zarazem sens i wskazuje wartość. Wartości zaś motywują ludzi do określonych zachowań i bardzo często utożsamiane są z celami, które jednostka zamierza osiągnąć. Dlatego zachowanie jednostek można wyjaśnić przez pryzmat dążenia do realizacji konkretnych cenionych obiektów. Wartości są jednocześnie kryterium samooceny, jak i narzędziem poznawczym oceny świata, formą ustosunkowania się do rzeczywistości, tak by ją zrozumieć i racjonalnie w niej funkcjonować.

Należy dodać, że każda wartość jest przez jednostkę poddawana indywidualnej interpretacji, co uzasadnia istnienie osobistych systemów wartości i ich organizacji, uhierarchizowania. Jeżeli podmiot działający bardziej preferuje jakąś wartość nad pozostałe, oznacza to, że zajmuje ona wyższą pozycję w hierarchii.

pedagogika kultury fizycznej i zdrowotnej Wydziału Nauk o Wychowaniu UŁ, piłkarze ŁKS i Widzew, Stowarzyszenie Projekt Polska i Komenda Miejska Policji w Łodzi. 
Dlatego wartości o wyższej pozycji są istotnym źródłem wskazówek postępowania jednostek.

Do pomiaru wartości wśród badanych kibiców4 posłużono się „Skalą Oceny Wartości" F. Kozaczuka, której dopełnieniem był autorski kwestionariusz ankiety. $Z$ analizy uzyskanych danych wynika, że grono respondentów stanowili jedynie pseudokibice płci męskiej, co w swojej ogólności oddaje istniejącą w tym zakresie prawidłowość badanego środowiska subkultury szalikowców.

Wśród przebadanych w 2008 roku najbardziej liczną i aktywną grupę stanowili fani w wieku 15-20 lat (43,3\% badanej populacji). Drugą pod względem liczebności warstwę tworzyli starsi kibice z przedziału wiekowego $21-29$ lat $(41,1 \%$ badanych). Natomiast ostatnią, najmniej liczną kategorią byli szalikowcy powyżej 30 . roku życia (15,6\% badanej populacji). W 2015 roku najbardziej liczną zbiorowość stanowili fani w wieku $21-29$ lat (59,2\% badanych), a dopiero potem byli to pseudokibice w wieku $15-20$ lat $(36,0 \%)$ i starsi szalikowcy po 30 . roku życia $(4,8 \%)$.

$\mathrm{Na}$ podstawie wypełnionych kwestionariuszy osobowych można stwierdzić, że badani w 2008 roku szalikowcy to ludzie charakteryzujący się niskim poziomem wykształcenia i że dominują wśród nich głównie osoby posiadające wykształcenie zawodowe $-39,4 \%$. Natomiast w 2015 roku w porównaniu do 2008 roku daje się zauważyć znaczącą zmianę w poziomie wykształcenia. W tym przypadku największą grupę stanowią respondenci z wykształceniem średnim - 39,8\%. Również pseudokibiców z wykształceniem wyższym jest więcej niż w roku 2008. Ich odsetek wzrósł z 10,1\% do 18,2\%. Powyższa sytuacja może mieć związek ze zwiększającym się przez ostatnie lata wskaźnikiem skolaryzacji dla Polski tudzież podniesieniem się wieku „przeciętnego” pseudokibica. Dokonując ogólnej charakterystyki badanej populacji, zapytano również respondentów o ich ewentualna przeszłość kryminalną. Z uzyskanych informacji wynika, że w 2008 roku konflikt z prawem deklarowało $15,56 \%$ z badanych osób, natomiast w 2015 roku 16,4\% respondentów.

Realizując przyjęty plan badawczy, za F. Kozaczukiem przedstawiono respondentom do oceny grupę 40 wybranych wartości należących do różnych kategorii obiektów, zarówno blisko ze sobą spokrewnionych znaczeniowo, np. miłość i przyjaźń, wiedza i wykształcenie, jak i odległych czy sobie przeciwstawnych, $\mathrm{np}$. rozwój duchowy a zabezpieczenie bytu, dobro moralne a dobro materialne. W ten sposób poszukiwano odpowiedzi, czy szalikowców łączy podobny system wartości. Jednocześnie, by dogłębniej zdiagnozować badany problem, polecono respondentom wybrać z listy pięć wartości i je uszeregować je według ich własnej skali ważności.

W 2008 roku badani, jak wynika z danych zawartych w tabeli 1, na pierwszym miejscu wśród cenionych przez siebie wartości ulokowali "godność osobistą" i „szacunek”. Takiego wyboru dokonał co dziesiąty respondent. Wśród wartości wskazanych przez szalikowców wysoko uplasowały się także władza, prawda

4 Badaniami objęto łącznie 303 zdeklarowanych szalikowców w roku 2008 i 2015 z terenu województwa śląskiego i małopolskiego, którzy stwierdzili, że „kibicują” takim drużynom, jak: GKS Katowice, Zagłębie Sosnowiec, Ruch Chorzów, Polonia Bytom, Górnik Zabrze, Wisła Kraków, Cracovia, Piast Gliwice. 
i „dobra materialne”. Badania porównawcze przeprowadzone w 2015 roku ujawniły, że wyznawane przez ankietowanych kibiców wartości nieco się zmieniły. Przede wszystkim zmniejszyła się liczba respondentów wskazujących na pierwszym miejscu wartość, jaką jest "godność osobista” - dla ankietowanych w 2015 roku kibiców najcenniejsze były bowiem „zdrowie” (9,6\%), „przyjaźń” (8,3\%) i „rodzina" (7,6\%). W uznawanej hierarchii wartości wysoko cenione są także te, które rodzajowo mieszczą się w kategorii tzw. wartości prestiżowych (władza, szacunek). Ogólnie można stwierdzić, że zarówno w 2008, jak i 2015 roku wśród szalikowców dominowały wartości o charakterze hedonistycznym. Niską rangę subkultura badanych pseudokibiców przypisywała wartościom społecznym. W swojej hierarchii wyborów szalikowcy praktycznie pomijali tzw. wartości adaptacyjne - to jest pomoc innym ludziom, odnalezienie swojego miejsca w świecie czy umiejętność współżycia z ludźmi. W dokonanej kategoryzacji respondenci nie przywiązywali również większej wagi do wartości intelektualnych (mądrość, wiedza) i obyczajowych (grzeczność, uprzejmość, tolerancja). Tendencje, jakie ujawniają się w deklarowanym systemie wartości, wskazują na przypisywanie coraz mniejszego znaczenia wierze religijnej i wykształceniu. Na znaczeniu zyskują natomiast patriotyzm i pokój. Dokonana przez respondentów segmentacja wartości generalnie w 2008 roku wskazywała, że szalikowcy w swoich wyborach prezentowali typową postawę egocentryczną nastawianą na własne dobro. W 2015 roku oprócz typowego egocentryzmu pojawiły się zalążki postaw związanych z socjocentryzmem (dobrem społecznym) i aliocentryzmem (nastawienie na dobro innego człowieka). Można więc powiedzieć, że nastąpiła nieznaczna poprawa ze sfery „mieć” na sferę „być”. Jest to o tyle ważne, że takie przewartościowanie wpływa w przyszłości na wybór odległych celów oraz sposób ich realizacji, czyli na plany życiowe jednostki.

Tabela 1. Wartość, „która jest na pierwszym miejscu w życiu”

\begin{tabular}{|c|l|c|c|}
\hline \multirow{2}{*}{ Lp. Kategorie odpowiedzi } & \multicolumn{2}{c|}{ \% odpowiedzi } \\
\cline { 3 - 4 } & & $\mathbf{2 0 0 8}$ & $\mathbf{2 0 1 5}$ \\
\hline 1. & Rodzina & 2,8 & 7,6 \\
\hline 2. & Radość życia & 5,0 & 4,0 \\
\hline 3. & Wygodne życie & 2,8 & 7,9 \\
\hline 4. & Wolność osobista & 2,8 & 2,9 \\
\hline 5. & Życie towarzyskie & 2,8 & 8,1 \\
\hline 6. & Szacunek & 10,0 & 5,2 \\
\hline 7. & Zabezpieczenie bytu & 2,8 & 4,6 \\
\hline 8. & Pokój & 0 & 3,4 \\
\hline 9. & Patriotyzm & 0 & 5,1 \\
\hline 10. & Własny rozwój & 0 & 2,1 \\
\hline 11. & Szczęście osobiste & 0 & 7,2 \\
\hline 12. & Odnalezienie swojego miejsca na świecie & 0 & 2,2 \\
\hline
\end{tabular}


Tabela 1 (cd.)

\begin{tabular}{|c|l|c|c|}
\hline \multirow{2}{*}{ Lp. Kategorie odpowiedzi } & \multicolumn{2}{c|}{$\%$ odpowiedzi } \\
\cline { 3 - 4 } & & $\mathbf{2 0 0 8}$ & $\mathbf{2 0 1 5}$ \\
\hline 13. & Zdrowie & 2,2 & 6,9 \\
\hline 14. & Władza & 7,2 & 10,6 \\
\hline 15. & Godność osobista & 11 & 5,9 \\
\hline 16. & Zainteresowania & 2,2 & 1,1 \\
\hline 17. & Prawda & 7,2 & 1,9 \\
\hline 18. & Praca zawodowa & 9,4 & 6,6 \\
\hline 19. & Pozycja społeczna & 2,8 & 0 \\
\hline 20. & Samodzielność & 5,6 & 0 \\
\hline 21. & Pomoc innym ludziom & 2,8 & 2,0 \\
\hline 22. & Umiejętność współżycia z ludźmi & 2,8 & 1,4 \\
\hline 23. & Dobra materialne & 7,2 & 4,0 \\
\hline 24. & Wiara w Boga & 2,8 & 2,0 \\
\hline 25. & Przyjaźń & 5,6 & 9,3 \\
\hline 26. & Mądrość & 2,2 & 2,3 \\
\hline Suma & & 100,0 & 100,0 \\
\hline
\end{tabular}

Wśród wartości wskazanych na drugim miejscu z rozkładu uzyskanych wyników wywnioskować można, że w 2008 roku respondenci najczęściej wybierali te wartości, które dotyczyły grupy wartości osobowych (godność osobista - 7,2\%, szczęście osobiste - 7,8\%, wolność osobista - 5,0\%, spokój wewnętrzny - 7,8\%). Popularne były również wybory w grupie wartości konsumpcyjnych (władza - 5\%, wygodne życie - 5,6\%, dobra materialne - 2,2\%) i wartości interpersonalnych (miłość - 5,6\%, radość życia - 5\%, przyjaźń - 4,4\%, wolność osobista - 5\%). Wysoko w rankingu tej kategorii szalikowcy plasowali również wartości związane z wartościami adaptacyjnymi, tj. samodzielność i szczęście. Zupełnie natomiast pomijali wartości dotyczące wiary, Boga, miłości bliźniego, życia wiecznego. W 2015 roku ankietowani na drugim miejscu w swoim życiu stawiali przede wszystkim na „szczęście osobiste” - 9,6\%, „rodzinę” - 7,2\%, „miłość” i szacunek (po 5,6\%). W swoich wyborach incydentalnie wskazywali lub pomijali wartości humanistyczne (piękno, pokój, poznanie świata, kształtowanie charakteru) i adaptacyjne (pomoc innym ludziom, odnalezienie swojego miejsca w świecie, umiejętność współżycia z ludźmi) - rozkład zmiennej przedstawia tabela 2.

Tabela 2. Wartość, „która jest na drugim miejscu w życiu”

\begin{tabular}{|c|l|c|c|}
\hline \multirow{2}{*}{ Lp. } & \multicolumn{2}{|c|}{ Kategorie odpowiedzi } & \multicolumn{2}{|c|}{ \% odpowiedzi } \\
\cline { 3 - 4 } & & $\mathbf{2 0 0 8}$ & $\mathbf{2 0 1 5}$ \\
\hline 1. & Rodzina & 2,8 & 6,3 \\
\hline 2. & Radość życia & 5,0 & 5,6 \\
\hline
\end{tabular}


Tabela 2 (cd.)

\begin{tabular}{|c|c|c|c|}
\hline 3. & Wygodne życie & 5,6 & 6,9 \\
\hline 4. & Wolność osobista & 5,0 & 3,1 \\
\hline 5. & Pokój & 2,2 & 2,9 \\
\hline 6. & Wykształcenie & 2,2 & 4,0 \\
\hline 7. & Szacunek & 5,0 & 9,6 \\
\hline 8. & Zabezpieczenie bytu & 2,8 & 4,6 \\
\hline 9. & Zdrowie & 2,8 & 6,0 \\
\hline 10. & Władza & 5,0 & 8,3 \\
\hline 11. & Poznanie świata & 2,8 & 1,0 \\
\hline 12. & Godność osobista & 7,2 & 3,0 \\
\hline 13. & Szczęście osobiste & 7,8 & 10,6 \\
\hline 14. & Odnalezienie swojego miejsca na świecie & 2,8 & 1,0 \\
\hline 15. & Kultura & 2,2 & 1,2 \\
\hline 16. & Pozycja społeczna & 7,2 & 2,0 \\
\hline 17. & Samodzielność & 2,2 & 4,2 \\
\hline 18. & Pomoc innym ludziom & 4,4 & 1,0 \\
\hline 19. & Umiejętność współżycia z ludźmi & 2,2 & 1,0 \\
\hline 20. & Spokój wewnętrzny & 7,8 & 3,3 \\
\hline 21. & Miłość & 5,6 & 9,6 \\
\hline 22. & Dobra materialne & 2,2 & 3,3 \\
\hline 23. & Przyjaźń & 4,4 & 5,3 \\
\hline 24. & Mądrość & 2,8 & 4,4 \\
\hline 25. & Życie towarzyskie & 0 & 5,3 \\
\hline 26. & Patriotyzm & 0 & 4,3 \\
\hline 27. & Własny rozwój & 0 & 2,3 \\
\hline 28. & Poznanie świata & 0 & 2,0 \\
\hline 29. & Zainteresowania & 0 & 2,6 \\
\hline \multicolumn{2}{|c|}{ Suma } & 100,0 & 100,0 \\
\hline
\end{tabular}

Na trzecim miejscu kibice w 2008 roku w hierarchii swoich wartości ulokowali „,rodzinę”, „wolność osobistą" i „szacunek”, które to wartości łącznie uzyskały $31,8 \%$ wszystkich wyborów. Podobnie sytuacja przedstawiała się wśród respondentów z 2015 roku (szczegółowy rozkład zmiennej przedstawia tabela 3). 
Tabela 3. Wartość, „która jest na trzecim miejscu w życiu”

\begin{tabular}{|c|c|c|c|}
\hline \multirow{2}{*}{ Lp. } & \multirow{2}{*}{ Kategorie odpowiedzi } & \multicolumn{2}{|c|}{$\%$ odpowiedzi } \\
\hline & & 2008 & 2015 \\
\hline 1. & Rodzina & 10,6 & 8,2 \\
\hline 2. & Realizacja zadania życiowego & 5,6 & 3,0 \\
\hline 3. & Wolność osobista & 10,6 & 7,6 \\
\hline 4. & Własny rozwój & 2,2 & 4,6 \\
\hline 5. & Szacunek & 10,6 & 15,1 \\
\hline 6. & Zabezpieczenie bytu & 5,6 & 6,3 \\
\hline 7. & Władza & 0 & 9,0 \\
\hline 8. & Zdrowie & 5,6 & 6,3 \\
\hline 9. & Piękno & 0,3 & 1,7 \\
\hline 10. & Szczęście osobiste & 2,8 & 5,6 \\
\hline 11. & Prawda & 5,6 & 6,3 \\
\hline 12. & Kultura & 2,2 & 2,3 \\
\hline 13. & Samodzielność & 2,2 & 4,3 \\
\hline 14. & Patriotyzm & 0 & 6,0 \\
\hline 15. & Pomoc innym ludziom & 5,0 & 4,3 \\
\hline 16. & Godność osobista & 0 & 3,3 \\
\hline 17. & Sprawiedliwość & 2,8 & 4,2 \\
\hline 18. & Spokój wewnętrzny & 2,2 & 1,8 \\
\hline 19. & Miłość & 6,7 & 9,3 \\
\hline 20. & Dobra materialne & 2,2 & 4,8 \\
\hline 21. & Wiara w Boga & 5,0 & 5,3 \\
\hline 22. & Przyjaźń & 7,8 & 8,9 \\
\hline 23. & Mądrość & 4,4 & 3,5 \\
\hline Suma & & 100,0 & 100,0 \\
\hline
\end{tabular}

\section{Wartości w życiu pseudokibiców dotyczące ich drużyny i klubu}

Obok wartości osobowych, mających istotne znaczenie dla konkretnej jednostki, istnieją wartości grupowe. To grupy ludzi i społeczeństwa nadają im określone znaczenie, uważają za niezmiernie ważne. Te wartości, ponadpersonalne, którym grupy przypisują określoną rangę i znaczenie, tworzą system wartości danego kręgu osób. W tym kontekście w prowadzonym badaniu poruszono również i tę kwestię, wiążąc ją z kibicowaniem i byciem kibicem.

W pierwszej kolejności zapytano badanych, co według nich oznacza być „prawdziwym kibicem”. Z przeprowadzonej analizy zgromadzonego materiału w 2008 roku wynikało, że bycie kibicem to przede wszystkim dopingowanie swojej 
drużyny, za czym opowiedziało się ponad 22\% przebadanych. Wśród kolejnych wymienianych najważniejszych stwierdzeń w tym względzie pojawiły się opinie wskazujące, że bycie prawdziwym kibicem to szacunek dla godła i barw klubowych $(16,1 \%)$, to bycie z drużyną w sytuacjach dobrych i złych $(10 \%)$ oraz systematyczne chodzenie na imprezy sportowe i udział w spotkaniach wyjazdowych klubu (14,4\%). Dla części respondentów w 2008 roku bycie kibicem kojarzyło się nie tyle z żywiołowym dopingiem, wiernością drużynie, znajomością zawodników czy chodzeniem na stadiony i podróżowaniem za klubem, lecz z niszczeniem barw i szalików drużyny przeciwnej (12,8\%), a także udziałem w zadymach (13,9\%).

Badania porównawcze przeprowadzone w 2015 roku potwierdziły, że nadal dla badanych szalikowców w byciu „prawdziwym kibicem” najważniejsze jest dopingowanie drużyny (26,5\%). Co siódmy uważa (16,9\%), że jest to miłość i szacunek do klubu, a co dziesiąty $(10,7 \%)$, że oznacza to bycie z drużyną na dobre i złe. Znaczna część respondentów zarówno w 2008 roku, jak i 2015 uznała, że bycie „prawdziwym kibicem” oznacza niszczenie barw i szalików drużyny przeciwnej czy też udział w zadymach. Szczegółowy rozkład wypowiedzi przedstawia tabela 4.

Tabela 4. Co oznacza być kibicem?

\begin{tabular}{|c|l|c|c|}
\hline \multirow{2}{*}{ Lp. } & \multicolumn{1}{|c|}{ Kategorie odpowiedzi } & \multicolumn{2}{c|}{ \% odpowiedzi } \\
\cline { 3 - 4 } & & $\mathbf{2 0 0 8}$ & $\mathbf{2 0 1 5}$ \\
\hline 1. & Dopingowanie drużyny & 22,8 & 26,5 \\
\hline 2. & Udział w zadymach & 13,9 & 18,2 \\
\hline 3. & Bycie z drużyną na dobre i na złe & 10,0 & 10,7 \\
\hline 4. & Szacunek do godła i barw klubowych & 16,1 & 16,9 \\
\hline 5. & Znajomość wszystkich członków drużyny & 5,0 & 8,3 \\
\hline 6. & Niszczenie barw, szalików drużyny przeciwnej & 12,8 & 17,8 \\
\hline 7. & Chodzenie na mecze swojej drużyny & 14,4 & 5,3 \\
\hline 8. & Bycie wiernym swojej drużynie & 5,0 & 4,3 \\
\hline Suma & & $\mathbf{1 0 0 , 0}$ & $\mathbf{1 0 0 , 0}$ \\
\hline
\end{tabular}

Czesław Matusewicz, wyjaśniając zjawisko identyfikacji kibiców z zespołami sportowymi, wskazywał, że utożsamianie się zaspokaja jedną z ważnych potrzeb ludzkich - potrzebę znaczenia. Kibic czuje się wtedy kimś ważnym, znaczącym. Bardzo często z tego właśnie powodu bywa na imprezach masowych. Inni autorzy badający wychowawcze problemy młodych kibiców sportowych podkreślają, jak bardzo ci młodzi ludzie pragną mieć poczucie przynależności do jakiejś grupy. Przy niemożności identyfikacji z grupą pozytywną odnajdują się w grupie negatywnej, to jest takiej, która nie akceptuje bądź jawnie łamie normy lub wartości akceptowane społecznie.

Podsumowując, należy stwierdzić, że badani szalikowcy w 2008 i 2015 roku na czołowych miejscach w hierarchii swoich wartości ulokowali przede wszystkim wartości hedonistyczne i społeczne. Za bardzo ważne w swoim życiu uznali 
również „szacunek” i „wolność osobistą”. Niską rangę przypisują natomiast wartościom humanistycznym (pięknu, kontaktowi z przyrodą, pokojowi, kształtowaniu charakteru, poznaniu świata) oraz wartościom prestiżowym (wykształceniu, spokojowi wewnętrznemu), czy też wartościom intelektualnym (mądrości, wiedzy) i religijnym. Dowodzi to, że zamiast żywych relacji i bliskości z innymi, w świecie wartości pseudokibiców dominuje konsumpcja zakłócająca w swojej istocie prawidłowy dialog z otoczeniem. Tym samym preferowanie przez szalikowców wartości pasywnych jest wymownym symptomem braku aksjologicznej wrażliwości, manifestacją przyzwolenia i godzenia się na wyrządzanie krzywdy przez ludzi czyniących zło. Jest jednocześnie ucieczką od odpowiedzialności, odchodzeniem od powinności moralnej, co świadczyłoby o wadliwym zinternalizowaniu norm i wartości współżycia społecznego. Podejście pseudokibiców do ich drużyny i klubu najkrócej można zobrazować słowami zaczerpniętymi z pamiętnika szalikowca: „Ja kibol swojej drużyny, identyfikuję się z nią. Moim przeciwnikiem jest to wszystko i ci wszyscy, którzy robią cokolwiek, by mojemu zespołowi przeszkodzić. Kto nie jest ze mną, jest przeciwko mnie! A kto jest przeciwko mnie, musi zostać ukarany. (...) Świat jest zły i podły, gdyż dybie na mnie, na mój klub. Ci, co myślą inaczej, są głupi i nienormalni".

Między badanymi szalikowcami z 2008 i 2015 występuje wspólnota systemu wartości strukturalnie ogniskujących się wokół wartości negatywnych. Skutkuje to w kolejnych „pokoleniach” pseudokibiców zacieraniem się granic między tym, co dobre, a tym, co złe, tym, co jest dozwolone człowiekowi jako istocie społecznej, a tym, co dozwolone mu nie jest.

Hierarchia wartości szalikowców z 2008 i 2015 roku charakteryzują się podobnym stopniem spójności. Stopień ten jest na tyle wysoki, że można mówić o stabilizowaniu się w grupie pseudokibiców jednolitej struktury wartości. Nie oznacza to, że nie ma między tymi dwoma grupami różnic. Występują one, ale są drugorzędnej natury.

\section{Wnioski}

Na podstawie dokonanej hierarchizacji wartości u przebadanych szalikowców można stwierdzić, że część z nich poprzez swoje wybory wykazuje symptomy osobowości antyspołecznej. Krzyżowe objawy tego stanu rzeczy to brak umiejętności dostosowania się do norm społecznych, który pociąga za sobą gotowość ze strony szalikowców do zachowań łamiących prawo, niezdolność do przeżywania poczucia winy, nieliczenie się z uczuciami innych, lekceważenie bezpieczeństwa własnego i innych.

Powyższe wnioski wskazują na pilną potrzebę nie tyle modernizowania rozwiązań prawnych, ile podjęcia przez szkołę niejako na nowo problemu wychowania moralnego, w tym edukacji w zakresie: dostarczania młodzieży wiedzy etycznej, kształtowania ocen, przekonań i postaw moralnych, ukazywania sposobów budowania osobistej hierarchii wartości, przygotowania do odpowiedzialnych zachowań w sytuacji zagrożeń zjawiskami patologicznymi. 
Współczesny system programowy nie przywiązuje większej wagi do kształtowania charakterów i postaw moralnych jako wyznaczników postępowania. Natomiast rzeczą bezsporną jest to, że prawidłowo ukształtowana osobowość jest w stanie oprzeć się wszelkiego rodzaju czynnikom kryminogennym. Sprzyja to zarazem afirmacji przez daną jednostkę ładu aksjonormatywnego nie poprzez nakaz, a wewnętrzną potrzebę na bazie uruchomionej świadomej refleksji. Jak przy tym podkreśla F. Kozaczuk, najważniejsza jest taka edukacja aksjologiczna, która ukazuje, jak potrzeby ludzkie przekształcać w wartości, takie jak: uczciwość, sprawiedliwość, prawość, przyjaźń, miłość, prawda, odpowiedzialność społeczna. Rozwijanie tych wartości w młodym pokoleniu Polaków byłoby najlepszą profilaktyką i jednocześnie środkiem kształtowania wewnętrznych mechanizmów postępowania w celu przeciwstawienia się destruktywnym wpływom socjokulturowym.

\section{Literatura}

Decyzja nr 57/2005 Komendanta Głównego Policji, Dziennik urzędowy Komendy Głównej Policji nr 6 , s. 190-194.

Kosiewicz J., Kultura fizyczna w perspektywie filozofii, Warszawa 2004, s. 191.

Kowalska J., Kaźmierczak A., Zasady fair play jako wartość wychowawcza w edukacji szkolnej i przeciwdziałaniu chuligaństwu stadionowemu, Warszawa 2010.

Krawczyk Z., Sport w zmieniającym się społeczeństwie, Warszawa 2000, s. 9, 13.

Krzyżak-Szymańska E., Szymański A., Niektóre wybrane dewiacje wśród dzieci i młodzieży na terenie województwa śląskiego, [w:] Bezpieczeństwo dzieci i młodzieży - zagrożenia cywilizacyjne w aspektach: pedagogicznym, instytucjonalnym i legislacyjnym, Mysłowice 2005, s. 15.

Matusewicz Cz., Psychologia wartości, PWN, Poznań 1975, s. 224.

Piotrowski P., Szalikowcy. O zachowaniach dewiacyjnych kibiców sportowych, Toruń 2000, s. 10-11.

Radawniak K., Z zagadnień charakterystyki i zwalczania chuligaństwa oraz przestępczości stadionowej z uwzględnieniem metody białego wywiadu, [w:] K. Budzowski (red.), Bezpieczeństwo, AMF, Kraków 2011, s. 37-38.

Rawicz J., Bylińska-Czemeszczyk Z., Mazierska E., Ostrowska W., Jewdikimow E., Godlewski, [w:] Encyklopedia Gazety Wyborczej, Mediasat Poland Sp. z o.o., 2005, t. 2, s. 337.

Skorupka S., Auderska H., Łempicka Z., Mały słownik języka polskiego, PWN, Warszawa 1990, s. 40. Uchwała nr X/110 z dnia 10.07.2010 Zarządu PZPN w sprawie przyjęcia Regulaminu w zakresie bezpieczeństwa podczas rozgrywek organizowanych przez PZPN i Ekstraklasa S.A.

Wiatr J.J., Społeczeństwo. Wstęp do socjologii, [w:] J. Woskowski (red.), Socjologia wychowania, Warszawa 1983, s. 59.

Wróblewski A., Sośniak K., Program edukacyjny „Bezpieczny i Przyjazny Stadion”, Katowice 2008, s. 3. 